\title{
UKOPAI, Android-Based Development of Competence Test for Arabic-Indonesian Translators
}

\author{
Moch. Syarif Hidayatullah \\ Translation Department \\ Universitas Islam Negeri Syarif Hidayatullah Jakarta, \\ Indonesia \\ moch.syarif@uinjkt.ac.id
}

\begin{abstract}
This study aims to develop an Android-based competency test for Arabic- English translators UjiKompetensiPenerjemah Arab-Indonesia (UKOPAI). This development research will use quiz model. From the five kinds of quizzes (multiple-choice, true/false, matching list, completion test, and fill in the blank),this research only use multiple choice quiz type. This research takes data resources in the form of materials and problems from competence test originated from the book TadribatTarjamah(2012) and other texts which are translated in the form of multiple choices with additional translation decoy. The problems and answers produced were tested using the translation assessment method from Machali(2000) and Hidayatullah (2017).After that it is produced in the form of application. The results of this research are in the form of android based Arabic-English translator competence test which are expected to be used by government or private institutions in recruiting employees and translation experts.
\end{abstract}

Keywords: UKOPAI, android application, competence test, Arabic-Indonesian translator

\section{INTRODUCTION}

In line with the rapid growth of the need for Arabic -Indonesian translation these days marked by the increasing need of Arabic texts to be translated by government and private institutions the requirement for professional translators are urgently required. Moreover, publishers of Islamic books in recent years require tenths up to hundreds of books to be translated.This does not include sworn or regular law documents translators and translations for Arabic movies which recently have gained the interests from the television industry.

Unfortunately, many publishers and service provider for sworn translators admit of having difficulties finding professional and quality translators(survey reports of Translation Department of Universitas Islam NegeriSyarifHidayatullah Jakarta2015).One of the causes is the absence of standards that are used in Indonesia to measure whether someone is considered to have fulfilled the qualifications as a translator or not. It is true that there already is a test for sworn translators, but so far for non-law texts translators there has not been any

\author{
Rifqi Fahrizal \\ Translation Department \\ Universitas Islam Negeri Syarif Hidayatullah Jakarta, \\ Indonesia \\ rifqifahrizal21@gmail.com
}

measurement tool that can be used to assess the their qualifications.

In this context, a measurement tool is required to identify whether someone fulfils the qualifications as a translator or not. Besides that, this measurement tool needs to be made by keeping up with the demand of time. In line with the development of technology, android-based platform applications become an alternative to ease the measurement and access by the society. Therefore, research on the development of android applications for competency test for ArabicIndonesian translators (UKOPAI) is needed. In the context of language, the researches on the development of android based application were still simple. So far there have not been found any researches on the development of application on language competence, especially the ability of translating Arabic-Indonesian texts.

\section{METHOD}

As has been mentioned previously, in a translation the result is assessed not the process. There are two kinds of assessment of translation that are proposed namely general and specific. The general way is that which can relatively be applied on any kinds of translation, whereas specific is what is specific for a certain text for instance text on law, text that functions aesthetically[3, p. 117]. In assessing a translation both the general and the specific, there are some stages that should not be skipped. The first step for instance is functional assessment stage, namely a general impression which shows the degree of understanding of a translator towards the source language. A thorough assessment is then conducted. In the initial stage, whether a translator has conducted a basic deviation in meanings or not should already be identified. Just like a general assessment, the deviation in referential meaning should be the determiner of an incorrect or an acceptable translation[3,p. 122].

In this assessment, there are aspects that are assessed and criteria that are used to assess the result of a translation. The way to asses a translation is also proposed, namely through specific indicators to determine whether a translation is good or not. A way to assess a translation through certain indicators to 
determine the quality of a translation with the range of almost perfect to bad was also proposed. The boundary line between a good and a bad translation is determined based on the existence of a deviation of reference meaning and how much it occurs [3,p. 122].

In the process of assessment, there is a step which is called measurement, which means an effort to acquire data or information quantitatively. In other words, measurement is an effort to know the condition of something as it is, in which the result can be quantified. This can be acquired by way of using or conducting test or through other means. Another definition states that measurement is comparing things with one quantitative measurement. In a measurement, the end result will always be in the form of numbers [4,p.2].

An assessment must follow the principals of validity and reliability. But as the assessment of translation is relative, then the validity of assessment can be viewed from the aspect of content validity and face validity. The reason being, assessing translation means looking at the aspect of content (content) also aspects related to readability such as spelling(face), although spelling itself is also related with meaning [3,p. 115]. The development of this application will use the theory of quiz making with model problem of multiple-choice, matching list, completion test and fill in the blank [5,p.15].

This research take data source in the form of materials and problems from competence test deriving from the bookTadribatTarjamah(2012)which is developed by Hidayatullahsince 2004 and have been used in trainings, practice and competency testing in translating Arabic-Indonesian texts within the Islamic Religious Colleges (PTKI) and various publishers. Besides from the book TadribatTarjamah, the problems in UKOPAIis taken from digital source originating from sites and books in classical or modern Arabic.

The materials and problems in the competence test originating from the book TadribatTarjamah, byHidayatullah[1] and other sources then translated as accurately as possible according to the Hidayatullahtheory [2], then decoy translations are made which serves as alternatives in the answer of multiple choices. After that, the answers are tested using the translation assessment theory from Machali[3] and Hidayatullah[2].

The book TadribatTarjamahcontains exercises on translations which are commonly used to hone in on the understanding of classical and modern Arabic texts along with the technique in translating it into Indonesian language. The book is usually used by the santri(Islamic boarding school student) and university students and the public at large who want to get a deeper understanding of Arabic texts and those who want to translate it into Indonesian language naturally, easily understood and pleasanttoread[1,p. vi]. On
October 2012 this book was published byAlkitabahin a revised edition in the eleventh print.The book became compulsory book within the university students in Tarjamah (Translation) Department at Faculty Adab and humanities Universitas Islam Negeri Syarif Hidayatullah Jakarta as practice materials in translating Arabic- Indonesian texts.

In this application development research, there are some processes and stages in the making of this application as follows: (a) application planning in which the existing problems are analyzed to know the aim of the development of application;(b)analyzing application requirements namely to analyze the requirements of the application whether functional or non-functional requirements of the application that is going to be made; (c) application designing which goes through some stages as follows: (1) designing the processes that the application can do;(2)designing the database structure required in the processes; (3) designing the user interface display of the application;(d)writing the program code.After the application design stage, conversion of the design system into the required programming language codes is conducted. After that, application assessment is carried out by trying out all the processes that have been implemented in the application using sample data.

Designing itself is the drawing, planning and making of the sketch or arrangement from numerous elements which are separated into one whole functional unity. System design can be designed in the form of flowchart system, which is a graphical means that can be used to show the sequences process of a system.

To be able to design a concept in making multimedia application, creativity is required. Creativity is the ability to present ideas or new ideas, whereas innovation is the application of ideas or new ideas. To create an original idea is not easy, thus some techniques to generate ideas can be utilized, namely adaptation, the existing multimedia is considered not in accordance with the intended environments. Every application has one scenario. To do the scenario, it requires an initial procedure in the process of running the application in the form of flowchart. The existing procedures in the system including the flow of data as follows: 


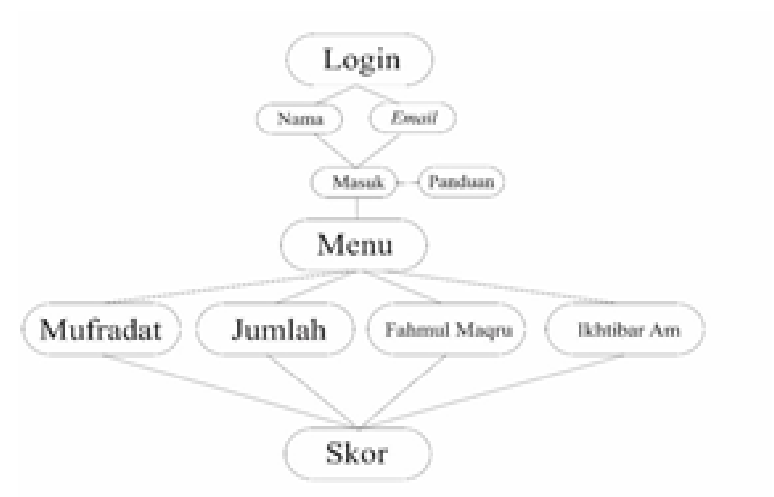

Figure 1. Diagram of the work process of application

The diagram above is a flowchart which depicts the work process system in running the application. Following is the explanation of the flowchart above:

1) when a user goes to the main page, the user will see the login display consisting of 2 columns namely name and email. Then click enter and the user will be directed to the guide page in using the application.

2) when a user is in the menu page there are 4 menu of problems namely the menu for questions on mufradat/words (50 questions), questions on jumlah/sentences (50 questions), questions on fahmulmaqru/reading comprehensions (50 questions), and questions on ikhtibaram/general evaluation (150 questions),

3) when a user chooses one of the menus of questions then the application will bring the user to the multiple-choice questions.

4) when a user finishes answering a question, the score display will appear.

5) when a user is in the score display there will be one menu button which when clicked will return to the main menu.

The working process system on the question as seen in the following diagram:

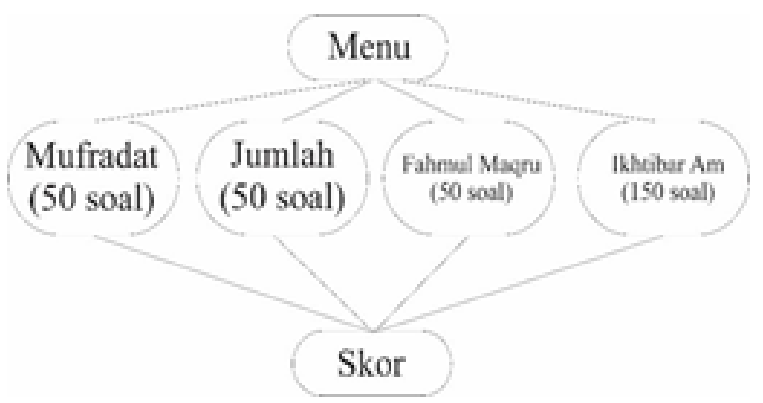

Figure 2. Flowchart of questions

In the question flowchart, the flow of data is shown on the menu level. When a user clicks the menu on mufrodat, the program will show 50 multiple-choice questions. If the user continues to choose IkhtibarAm, then 150 multiple-choice questions will appear. After the user answers the questions, the system will automatically asses based on the language program code that had been created.

\section{RESULTS AND DISCUSSION}

In making the android based application UKOPAI, the questions are grouped into three groups based on the competence that intended to be tested: (1) mufradat and tarkib (phrases); (2) jumlah; (3) fahmul maqru. The group on mufradat and tarkib questions is used to test the competence on the repertoire of vocabulary, diction choice and phrases forms. Questions on the jumlah questionsare used to test the competence in recognizing the different grammatical constructions between the source language and the target language and the implications in translation activities. The question on fahmul maqru group are used to test the understanding of texts.

Each group of questions consists of 50 questions. In the test the questions on the mufradat and tarkib group have the maximum time limit of 35 minutes. The questions on the jumlah group have the maximum time limit of 45 minutes. The questions on the fahmul maqru group has the maximum time limit of 40minutes. The total time needed is 120 minutes.

The different time limit required to finish for each question has to do with the level of complexity of the question. In the UKOPAI application, the total questions from the three competences are also provided. The user can clickon the ikhtibar am button to do the whole questions. The number of questions and the time needed to do it is the same that is 120 minutes. In this sub chapter, some UKOPAI questions will be analyzed as samples. The questions are taken randomly to represent each question group.

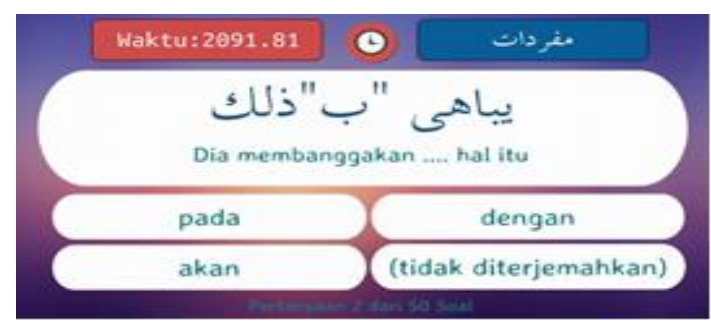

Figure 3. Display of question number 2

The letter $\varphi$ is a particle of preposition which can only accompany ismwhich in Indonesian language can be translated into di, dengan, melalui[6,p. 288]. Whereas the wordwmeans to race against one another,to compete,to pride themselves[7,p. 135], and the word ذلك ismisyarahwhich means itu, ini[6,p. 934].The translation of the clause يباهيبذلك is "he boasts about it". The correct answer of the question in the picture lies in the column "(not translated)", because in line with the principle of Indonesian language that verbs with affixes of me-kanhas to be directly adjacent to the object. 
Besides related to responsibility of the questions this subchapter will explain how the UKOPAI application asses or give scores so that the user can know or see the result after answering the translation questions. The scoring of the work of test participants to acquire a score is conducted right after the test is done. The sooner scoring is done, the better it will be all the interested parties in the test. Not only the test participants but also other parties such as instructors, the organizers, parents of learners and other parties[4, p. 210].

The answer key or the scoring key is made first by determining the position of the correct answers. In determining the score for the true or false type questions, two ways are used, those are; without punishment (fine)or by using punishment.

1) Without punishments

This way of scoring makes the answers of the test which are suitable with the answer key the participant's score.

2) With punishment or guessing formula

$$
\begin{aligned}
& \text { S }=\text { Score }=\mathrm{R}-\mathrm{W} \\
& \mathrm{R}=\text { Right (number of correct answers) } \\
& \mathrm{W}=\text { Wrong (number of incorrect answers) } \\
& \text { For example: } \\
& \text { - Number of questions } \quad: 10 \\
& \text { - Correct answers } \quad: 8 \\
& \text { - Incorrect answers } \quad: 2 \\
& \text { - The score }: 8-2=6 \\
& \text { The second formula: } \\
& \text { S + T-2W } \quad: 10 \\
& \text { For example: } \\
& \text { - Questions } \\
& \text { - Incorrect answers } \quad: 2 \\
& \text { - The score } \\
& \text { 10 - } 4=6
\end{aligned}
$$

The formula with punishments is based on the consideration that there is a strong element of guess.

Besides the true or false type questions this application also applies multiple choice type of questions. With the multiple-choice type questions participants are asked to choose by touching the button in the question in the application. In determining the answer key for this type of questions is almost the same with the true or false type questions which has 2 ways of assessment that is with punishment and without punishments [4, p. 212]. The formula with punishments is as follows:

$$
\mathrm{S}=\mathrm{R}-\underline{\mathrm{W}} \underset{(\mathrm{n}-1)}{ }
$$

Example:

- Questions : 10

- Incorrect answers : 8

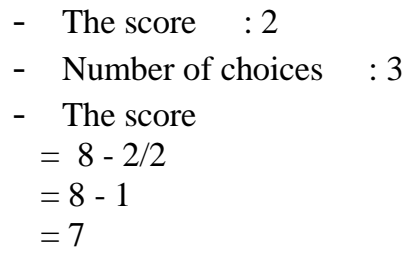

For the score in application, the writer has determined two types of questions, the first containing 50 questions and the second containing 150 questions with a score of 4,4 for every question. If a user has answered the first type of question containing 50 questions all correctly then the score will be 220 . If the second type of questions containing 150 questions are answered correctly then the score is 660 .

\begin{tabular}{|c|c|c|}
\hline Questions & $\begin{array}{c}\text { Correct } \\
\text { Answers }\end{array}$ & Score \\
\hline 50 & 37 & 162 \\
\hline 150 & 67 & 277 \\
\hline
\end{tabular}

Table 1. Total Question Score

In the table above, the author uses of arithmetic operation namely multiplication. For example in the first picture it can be seen that the number of questions are 50 and there are 37 correct answers so the scoring work system of the application, the correct answers $37 \times 4,4$ which resulted in the score of 167 . In the display of result of score or assessment, the researcher also gives indication of the score that the translator gets in the form of 5 stars. The number of star indicates the quality of the translation of the participant of translator.

1) 50questions

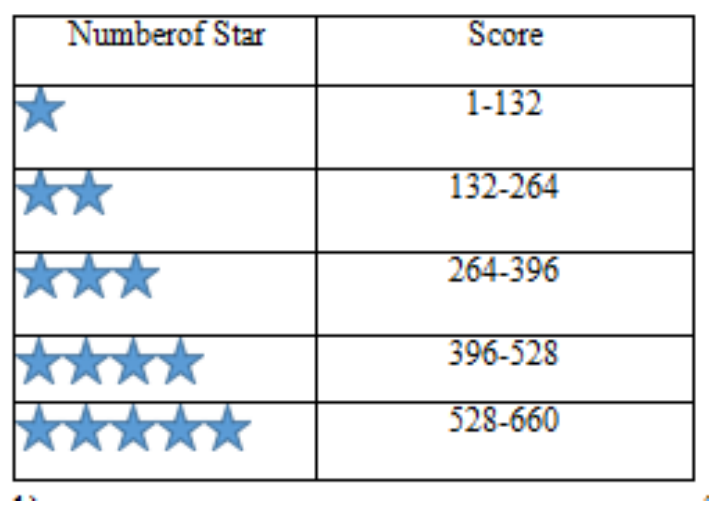

Table 2. Display of scores in the UKOPAI application 
2) 150 questions

\begin{tabular}{|c|c|}
\hline Number of Star & Score \\
\hline 充 & $1-44$ \\
\hline 交索 & $44-88$ \\
\hline 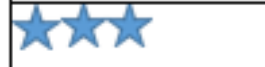 & $88-132$ \\
\hline 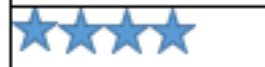 & $132-176$ \\
\hline 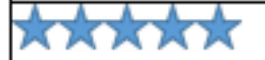 & $176-220$ \\
\hline
\end{tabular}

Table 3. Display of scores in the UKOPAI application

The picture above shows the display of scores in the UKOPAI application. Stars will appear based on the scores which has been determined by the researcher. The indication of stars that the participants acquire will give an interesting and exciting experience in learning.

The designs that have been designed are then translated into codes through events to implement the logic of the program. The implementation process is conducted on the development software. The software testing process is done to ensure that the software that is developed has been running properly. In the production of this UKOPAI application, the author provides multiplatform which enables the developed application can run in various platforms such as Windows, Android, IOS. For windows, windows version seven above is required. As for Android the minimum requirement is version 4.0.4(Jellybean) and requires a minimum $R A M$ of $1 G B$. For IOS, it requires minimum version of IOS 6 above.

\section{CONCLUSION AND RECOMMENDATION}

Based on the result of the research that has been carried out in developing android based UKOPAI application, it can be concluded that the process of making a translation quiz is done through several stages, starting from data analysis, application planning, background and button design making, up to testing the application so that it can run perfectly. The stages are carried out to ease users in testing their ability and competence in translating ArabicIndonesian texts. Not only to test, users also can train their translation skills from Arabic-Indonesian. The UKOPAI application is equipped with scoring features in the practice so that they can have a reference of how proficient they are in translating.
There are still some weaknesses in this application. For instance, there is only one group of questions thus making a user who had answered the questions in the application to recognize the existing questions. This application also has not developed in realtime by utilizing a server so that it can be used to have translation competence competition which leads to a game. Another weakness is the unavailability login system using Facebook or other social media that are widely used by the general public. It will also be useful if the application can print e-certificate after participants have taken the tests. Thus, we recommend that this UKOPAI application can be developed in line with needs and the direct development in the society.

\section{REFERENCES}

[1] M.S. Hidayatullah, Tadribat Tarjamah, Tangerang: Dikara, 2012.

[2] M.S. Hidayatullah, Jembatan Kata: Seluk-Beluk Penerjemahan Arab-Indonesia, Jakarta: Grasindo, 2017.

[3] RochayahMachali,Pedoman Bagi Penerjemah, Jakarta:Grasindo2000.

[4] Moh. Mastna, Pengembangan Evaluasidan Tes Bahasa Arab, Tangerang: Alkitabah, 2012.

[5] AriefHidayat, Rancang Bangun Sistem Kuis Online Adaptif sebagai Ekstensi Content Management System, Skripsi, UniversitasDiponegoro Semarang, 2011.

[6] Atabik Ali and Ahmad ZuhdiMudlor, Kamus Krapyak al-Asri, Yogyakarta: Multi KaryaGrafika, 1998.

[7] MunirBaalbaki andRohiBaalbaki, Kamus Al Maurid ArabInggris-Indonesia, Surabaya: Halim Jaya, 2006 